Journal of Community Based Environmental Engineering and Management, 2019, Vol. 3, No. 1: 25-32

\title{
KAJIAN MENGENAI PANDANGAN PENGGUNA TERHADAP SARANA SANITASI DI SMK NEGERI COMPRENG, KABUPATEN SUBANG
}

\author{
Deni Rusmaya*, Hary Pradiko, Reviardi Redi Nugroho \\ Program Studi Teknik Lingkungan, Universitas Pasundan
}

\begin{abstract}
Abstrak
Sarana sanitasi sekolah merupakan kebutuhan penting yang harus diperhatikan kualitas dan kuantitasnya untuk menjaga kondisi lingkungan dan kesehatan tetap baik dan terjaga. SMK Negeri Compreng merupakan satu-satunya sekolah kejuruan yang terdapat di Kecamatan Compreng, Kabupaten Subang. Kajian ini bertujuan untuk mengetahui permasalahan yang terdapat di SMK Negeri Compreng berkaitan dengan fasilitas sanitasi berdasarkan pandangan penggunanya. Metode yang digunakan adalah penyebaran kuisioner terhadap pengguna fasilitas sanitasi. Berdasarkan survey tersebut, diperoleh bahwa sebanyak responden 79,4\% berpendapat fasilitas air bersih layak. Sedangkan terhadap fasilitas air limbah, terdapat $62,9 \%$ responden yang berpendapat fasilitas tersebut layak. Responden yang menyatakan bahwa fasilitas drainase layak hanya 32,4\%, sedangkan yang menyatakan bahwa fasilitas pengelolaan sampah layak adalah 40,8\%. Dilihat secara keseluruhan fasilitas sanitasi, sebanyak 54\% responden menyatakan masih layak digunakan. Hasil kajian memperlihatkan bahwa prioritas perbaikan fasilitas sanitasi adalah pada sarana drainase dan pengelolaan sampah.
\end{abstract}

Kata kunci: Sanitasi sekolah, pendapat pengguna, kuisioner

\section{Pendahuluan}

Kondisi kesehatan lingkungan sekolah hanya dapat tercapai apabila didukung oleh peran serta dan keterlibatan semua pihak baik pemerintah, swasta maupun masyarakat terutama warga lingkungan sekolah. Proses belajar mengajar di sekolah dapat terganggu jika penanganan sanitasi tidak dilakukan dengan baik (Santi \& Bahiij, 2018). Penanganan masalah sistem sanitasi di sekolah-sekolah sampai saat ini masih belum mendapat prioritas tinggi. Kondisi ini terlihat dari masih banyaknya kita jumpai sekolah-sekolah yang belum mempunyai sarana sanitasi di sekolah yang baik agar tercipta lingkungan sekolah yang sehat demi menunjang kegiatan belajar mengajar di sekolah.

${ }^{*}$ Penulis Korespondensi:

E-mail: denirusmaya@gmail.com

Diterima pertama kali: 7 Januari 2019

Direvisi : 21 Januari 201

Disetujui untuk publikasi: 23 Januari 2019
Bab V pasal 45 Undang-Undang No. 36 Tahun 2014 tentang kesehatan menyebutkan bahwa kesehatan diselenggarakan untuk meningkatkan kemampuan hidup sehat peserta didik (anak sekolah) dalam lingkungan hidup sehat sehingga peserta didik dapat belajar, tumbuh dan berkembang secara harmonis dan optimal untuk menjadi sumber daya manusia yang lebih berkualitas.

Dengan masih kurangnya sarana dan prasarana sanitasi yang baik, biasanya para siswa di sekolah yang paling terdampak. Karena bukan saja disebabkan oleh kurang memadainya sarana tetapi juga kurangnya pengetahuan dan bimbingan yang didapat dari guru maupun orang tua di rumah serta kesadaran untuk melakukan pola hidup sehat, baik di sekolah maupun di rumah. Akibatnya pengaruh yang melemahkan dari kondisi hidup yang kurang sehat tersebut sangat mempengaruhi kemampuan anak didik dalam peningkatan sumber daya manusia yang 
berkualitas dan menghambat proses kegiatan belajar-mengajar di sekolah.

Menurut PERPRES No.185 Tahun 2014 sanitasi adalah segala upaya yang dilakukan untuk menjamin terwujudnya kondisi yang memenuhi persyaratan kesehatan melalui pembangunan sanitasi.

Pembangunan sanitasi adalah upaya peningkatan kualitas dan perluasan pelayanan persampahan rumah tangga, air limbah domestik dan pengelolaan drainase lingkungan secara terpadu dan berkelanjutan melalui peningkatan perencanaan, kelembagaan, pelaksanaan dan pengawasan yang baik.

Sekolah Menengah Kejuruan (SMK) Negeri Compreng yang terletak di Jalan Raya Compreng, RT/RW 9/2, Dusun Mekarsari, Desa Mekarjaya, Kecamatan Compreng, Kabupaten Subang, Jawa Barat merupakan satu-satunya sekolah kejuruan negeri yang ada di Kecamatan Compreng.

SMK Negeri Compreng merupakan sekolah yang baru mandiri dimana sebelumnya SMK Negeri Compreng merupakan sekolah filial dari SMK Negeri 2 Subang. SMK Negeri Compreng diresmikan oleh pemerintah pada tahun 2014 dengan memiliki luas tanah sebesar $10.000 \mathrm{~m}^{2}$ yang didalamnya terdapat beberapa fasilitas seperti gedung kegiatan belajar mengajar, gedung pengajar, gedung ekstra kulikuler, dan gedung bengkel. SMK Negeri Compreng memiliki sistem pendidikan semi-taruna dengan penghuni sekolah sebanyak 375 orang.

Maksud dari dilakukannya penelitian ini adalah untuk mengidentifikasi permsalahan yang terdapat pada fasilitas sanitasi di SMK Negeri Compreng melalui jajak pendapat penggunanya.

\section{Metodologi}

\section{Umum}

Metode yang digunakan dalam perencanaan ini adalah metode deskriptif yang lazim digunakan dalam pengumpulan data, baik data primer maupun data sekunder yang biasanya dilaksanakan dalam bentuk teknik survey dengan kuisoner dan pengamatan di lapangan.

Data primer diambil berdasarkan simple random sampling yaitu pengambilan sampel kepada populasi responden dimana pemilihan sampel sederhana secara acak tanpa memperhatikan strata yang ada di dalam populasi tersebut. Untuk menentukan ukuran sampel dari populasi penulis menggunakan rumus Slovin (Sevilla \& al, 2007) sebagai berikut :

$\mathrm{n}=\frac{N}{1+N e^{2}}$

Dimana :

n : ukuran sampel

$\mathrm{N}$ : ukuran populasi

e : nilai kritis (batas penelitian) yang diinginkan (persen kelonggaran ketidak telitian karena kesalahan pengambilan sampel populasi).

\section{Pengumpulan Literatur}

Pengumpulan literatur yaitu studi pendahuluan dilakukan untuk memperoleh dasar yang kuat yang dapat mendukung penelitian dan untuk mengetahui data apa saja yang dibutuhkan serta darimana atau siapa data tersebut dapat diperoleh untuk menentukan cara menganalisa data.

\section{- Sanitasi Sekolah}

Pengertian sanitasi adalah usaha kesehatan dan pencegahan terhadap penyakit dengan memelihara lingkungan yang sehar dan bersih (Atmoko, 2017). Sarana kesehatan sekolah untuk mendukung sanitasi adalah kamar mandi, tempat cuci tangan dan kakus.

\section{- Air Bersih}

Air bersih adalah salah satu jenis sumberdaya berbasis air yang bermutu baik dan biasa dimanfaatkan oleh manusia untuk dikonsumsi atau dalam melakukan aktivitas mereka seharihari termasuk diantaranya adalah sanitasi. 


\section{- Air Buangan}

Air buangan adalah air yang telah mengalami penurunan kualitas akibat pengaruh aktifitasi manusia.

\section{- Persampahan}

Pengelolaan sampah atau biasa disebut persampahan adalah pengumpulan, pengangkutan, pemrosesan, daur ulang, atau pembuangan dari material sampah

\section{- Drainase}

Drainase atau pengatusan adalah pembuangan massa air secara alami atau buatan dari permukaan atau bawah permukaan dari suatu tempat. Pembuangan ini dapat dilakukan dengan mengalirkan, menguras, membuang, atau mengalihkan air.

\section{Pengumpulan Data Primer}

\section{- Air Bersih}

Pengumpulan data primer sarana air bersih yaitu dengan mengidentifikasi masalah sarana air bersih menggunakan metode pengamatan dan kuisoner yang disebar ke responden.

\section{- Air Buangan}

Pengumpulan data primer untuk air buangan adalah menghitung jumlah siswa yang menggunakan toilet, dengan cara melakukan pengamatan dan kuisoner.

\section{- Persampahan}

Pengumpulan data primer untuk sarana persampahan adalah mengenai timbulan, komposisi, dan karakteristik sampah melalui pengamatan selama 5 hari dan juga kuisoner.

\section{- Drainase}

Pengumpulan data primer sarana drainase adalah dengan mengidentifikasi masalah yang terjadi di sekolah seperti adanya banjir atau genangan jika terjadi hujan dan juiga dengan metode kuisoner.

\section{Data Sekunder}

\section{- Air Bersih}

Data sekunder meliputi keadaan umum atau gambaran wilayah studi, data ini merupakan data tentang kondisi daerah studi, jumlah siswa dan staff pengajar SMK Negeri Compreng serta fasilitas yang ada dilokasi studi dan data standar kebutuhan air bersih.

\section{- Air Buangan}

Data sekunder yang digunakan pada air buangan adalah standar jumlah air limbah di pemukiman (rumah tangga), dan jumlah siswa serta staff pengajar SMK Negeri Compreng yang berada di lingkungan studi.

\section{Analisa Dan Perhitungan}

Analisa terbagi menjadi dua, yaitu analisa yang dilakukan sebelum perhitungan dan analisa yang dilakukan setelah melakukan perhitungan. Analisa yang dilakukan sebelum perhitungan adalah analisa terhadap kondisi daerah studi yang dilakukan dengan cara melihat secara seksama kondisi-kondisi yang sudah tidak memungkinkan untuk dipergunakan kembali.

\section{Hasil dan Pembahasan}

\section{Penentuan Jumlah Responden Kuisoner}

Masalah sanitasi yang terjadi di daerah studi diketahui dari hasil pengamatan dan survey penyebaran kuisoner terhadap siswa dan staff pengajar sarana prasarana di SMK Negeri Compreng. Total siswa di SMK Negeri Compreng berdasarkan jenis kelamin yaitu 192 laki-laki, dan 157 perempuan.

Penentuan jumlah responden diperoleh dari hasil perhitungan Slovin.

$>$ Perhitungan responden siswa:

$$
\begin{aligned}
& n=\frac{N}{1+N e^{2}} \\
& n=\frac{N}{1+N e^{2}}=\frac{349}{1+349 \times 0,1^{2}}=77,73=78 \\
& \text { Responden } \\
& f i=\frac{n i}{N} \\
& n i=f i \times n
\end{aligned}
$$


Jumlah siswa perempuan: 157 siswa

$$
\begin{aligned}
f i=\frac{157}{349}=0,45 & \times 78 \\
= & 35 \text { Responden }
\end{aligned}
$$

Perhitungan responden siswa laki-laki:

Jumlah siswa laki-laki: 192 siswa

$$
\begin{aligned}
f i=\frac{192}{349}=0,55 & \times 78 \\
= & 43 \text { Responden }
\end{aligned}
$$

Tabel 1 memperlihatkan jumlah sampel yang dijadikan responden berdasarkan jenis kelaminnya, sedangkan Gambar 1 memperlihatkan persentase jenis kelamin responden.

Tabel 1. Jumlah Sampel Responden

\begin{tabular}{cc}
\hline $\begin{array}{c}\text { Jenis } \\
\text { Kelamin }\end{array}$ & $\begin{array}{c}\text { Jumlah } \\
\text { Sampel }\end{array}$ \\
\hline Perempuan & 35 \\
\hline Laki-Laki & 43 \\
\hline Total & 78 \\
\hline
\end{tabular}

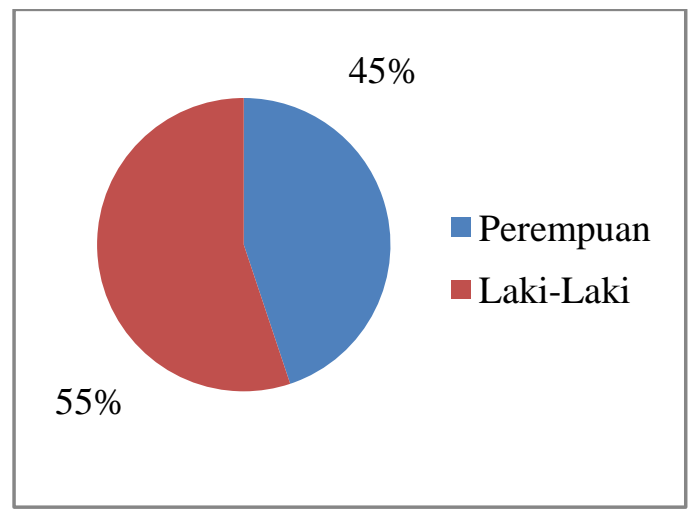

Gambar 1. Persentase Jenis Kelamin Responden

Tabel 1 dan Gambar 1 menunjukkan bahwa jumlah responden lak-laki lebih banyak dibandingkan dengan responden perempuan.

\section{Kualitas Air Bersih}

Gambar 2 memperlihatkan pendapat responden laki-laki (siswa) terhadap kualitas air bersih dari parameter bau. Sebanyak $74 \%$ responden siswa menyatakan air bersih tidak berbau.

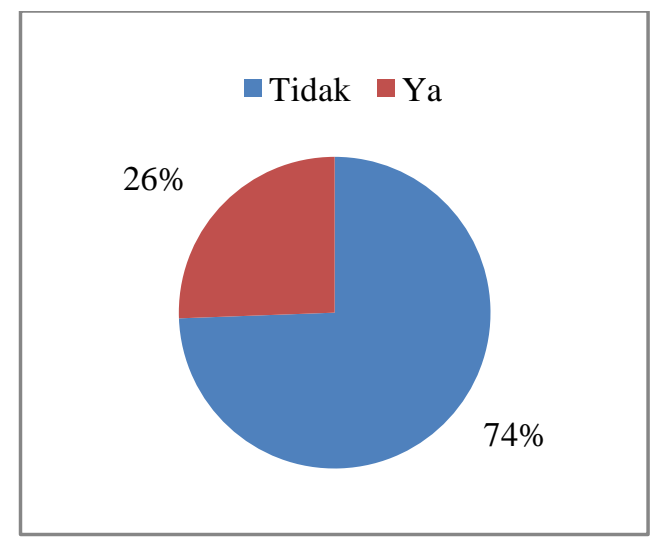

Gambar 2. Pendapat responden laki-laki terhadap kualitas air (parameter bau)

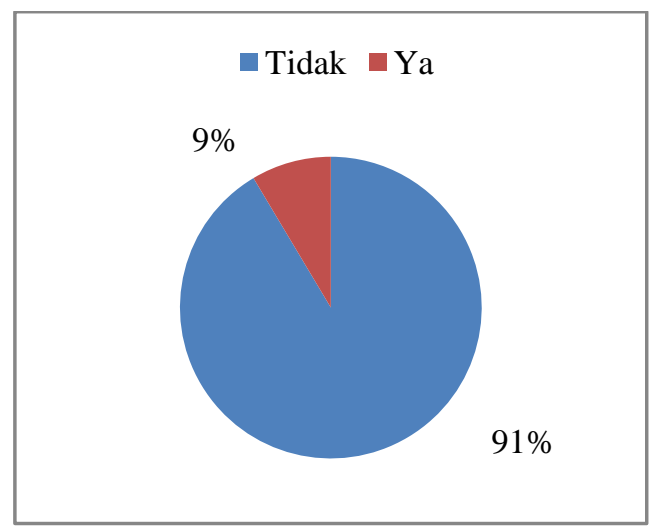

Gambar 3. Pendapat responden perempuan terhadap kualitas air (parameter bau)

Gambar 2 dan 3 menunjukkan bahwa dari 43 responden siswa laki-laki yang menjawab bahwa air bersih tidak memiliki bau yaitu sebanyak $74 \%$, dan yang menjawab bahwa air bersih memiliki bau sebanyak 26\%. Sedangkan dari 35 responden siswa perempuan yang menjawab bahwa air bersih tidak memiliki bau yaitu sebanyak $91 \%$, dan yang menjawab bahwa air bersih memiliki bau sebanyak $9 \%$.

Gambar 4 dan 5 memperlihatkan bahwa dari 43 responden siswa laki-laki yang menjawab bahwa air bersih tidak digunakan untuk minum yaitu sebanyak $98 \%$, dan yang menjawab bahwa air bersih digunakan untuk minum sebanyak $2 \%$.

Sedangkan dari 35 responden siswa perempuan yang menjawab bahwa air bersih tidak digunakan untuk minum yaitu sebanyak 94\%, 
dan yang menjawab bahwa air bersih digunakan untuk minum sebanyak $6 \%$.

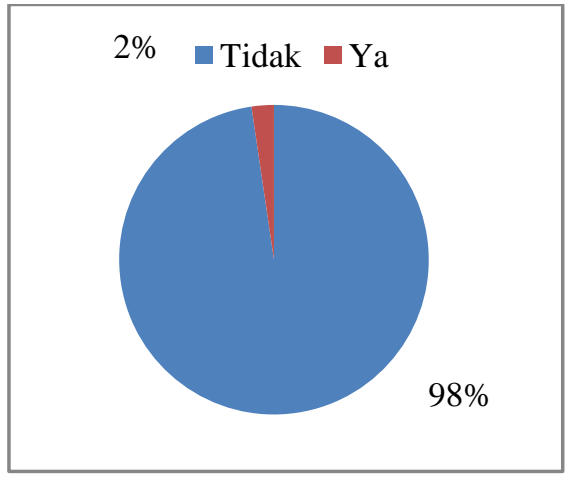

Gambar 4. Pernyataan responden laki-laki mengenai penggunaan air bersih untuk air minum

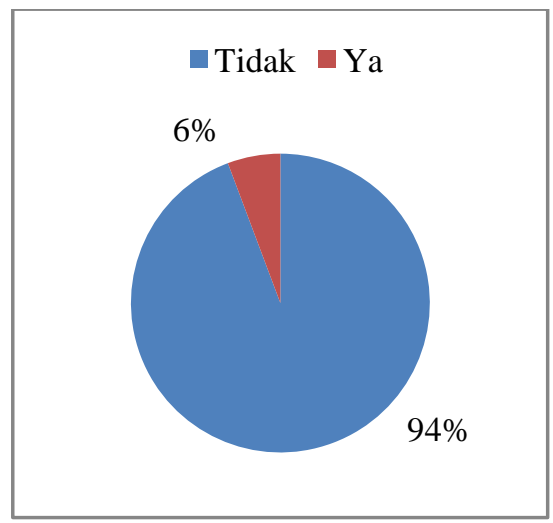

Gambar 5. Pernyataan responden perempuan mengenai penggunaan air bersih untuk air minum

\section{Kondisi Air Buangan}

Gambar 6 dan Gambar 7 memperlihatkan hasil kuisioner mengenai air buangan.

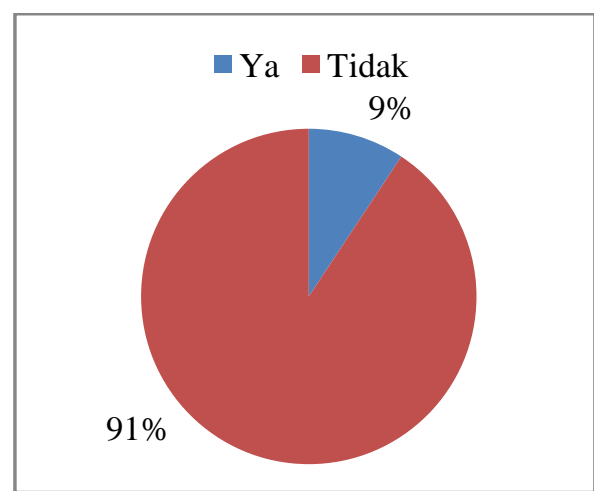

Gambar 6. Pendapat responden laki-laki bahwa Jamban/Toilet dalam kondisi bersih

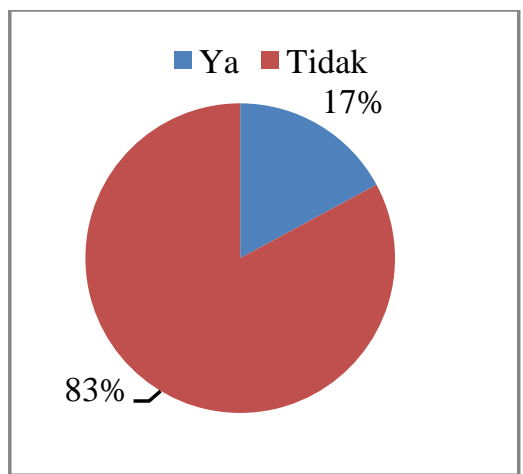

Gambar 7. Pendapat responden perempuan bahwa Jamban/Toilet dalam kondisi bersih

Dari 43 responden siswa laki-laki, yang menjawab bahwa jamban/toilet dalam keadaan bersih dari kotoran yaitu sebanyak $9 \%$, dan yang menjawab jamban/toilet dalam keadaan tidak bersih dari kotoran yaitu sebanyak 91\%. Sedangkan dari 35 responden siswa perempuan yang menjawab bahwa jumlah jamban/toilet dalam keadaan bersih dari kotoran yaitu sebanyak 17\%, dan yang menjawab jumlah jamban/toilet dalam keadaan tidak bersih dari kotoran yaitu sebanyak $83 \%$.

Terdapat 2 peruntukan jamban/ toilet yang terdapat di SMK Negeri Compreng yaitu untuk guru dan untuk siswa. Dari 43 responden siswa laki-laki, yang menjawab bahwa jamban/toilet siswa dan guru tidak dipakai bersamaan yaitu sebanyak $35 \%$, dan yang menjawab jamban/toilet dipakai bersamaan yaitu sebanyak 65\%. Sedangkan dari 35 responden siswa perempuan yang menjawab jamban/toilet siswa dan guru tidak dipakai bersamaan yaitu sebanyak 29\%, dan yang menjawab jamban/toilet siswa dan guru dipakai bersamaan yaitu sebanyak $71 \%$.

\section{Kondisi Fasilitas Drainase}

Gambar 8 dan Gambar 9 memperlihatkan hasil kuisioner mengenai kondisi genangan atau banjir yang terjadi.

Gambar 8 dan 9 tersebut menunjukkan bawah dari 43 responden siswa laki-laki, yang menjawab bahwa saat musim hujan terjadi banjir yaitu sebanyak $86 \%$, dan yang menjawab saat 
musim hujan tidak terjadi banjir yaitu sebanyak 14\%. Sedangkan dari 35 responden siswa perempuan yang manjawab saat musim hujan terjadi banjir yaitu sebanyak $88 \%$, dan yang menjawab saat musim hujan tidak terjadi banjir yaitu sebanyak $12 \%$.

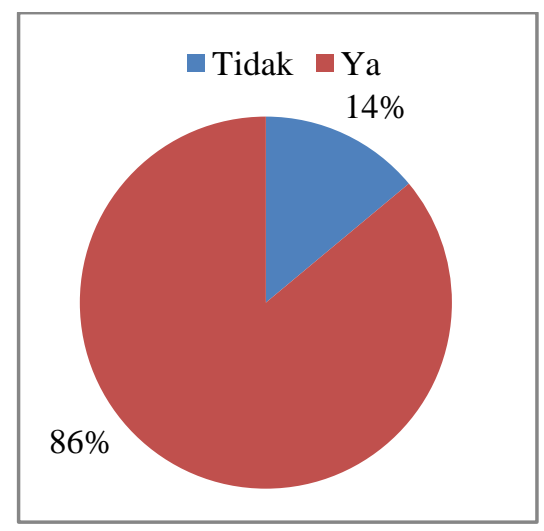

Gambar 8. Pernyataan responden laki-laki terhadap kejadian banjir di sekolah

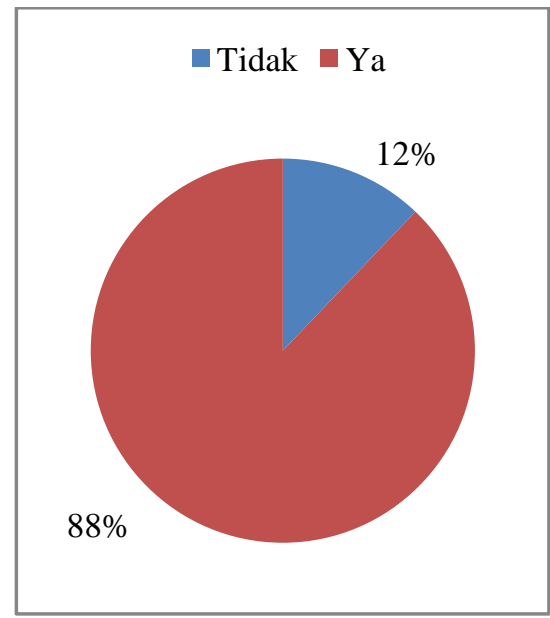

Gambar 9. Pernyataan responden perempuan terhadap kejadian banjir di sekolah

Gambar 10 dan 11 menunjukkan bahwa dari 43 responden siswa laki-laki, yang menjawab bahwa saluran air dalam keadaan tidak layak dan terawat yaitu sebanyak 56\%, dan yang menjawab saluran air dalam keadaan layak dan terawat sebanyak 44\%. Sedangkan dari 35 responden siswa perempuan, yang menjawab saluran air dalam keadaan layak dan terawat yaitu sebanyak 36\%, dan yang menjawab saluran air dalam keadaan tidak layak dan terawat yaitu sebanyak $64 \%$.

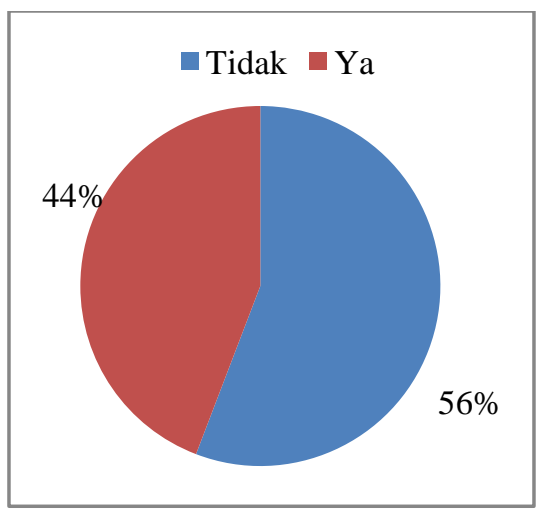

Gambar 10. Pendapat responden laki-laki terhadap kelayakan saluran drainase

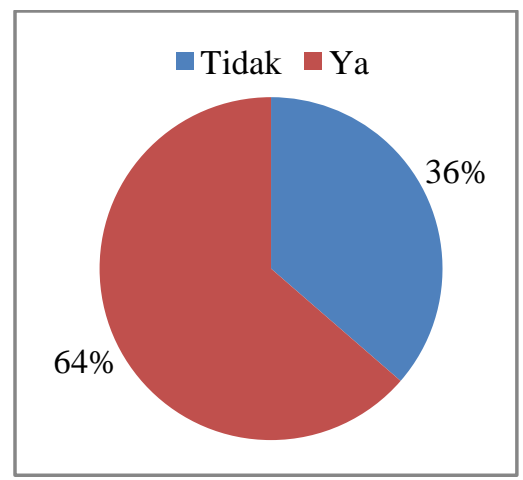

Gambar 11. Pendapat responden perempuan terhadap kelayakan saluran drainase

\section{Kondisi Pengelolaan Persampahan}

Gambar 12 dan Gambar 13 memperlihatkan hasil kuisioner mengenai kondisi pengelolaan sampah di SMK Negeri Compreng.

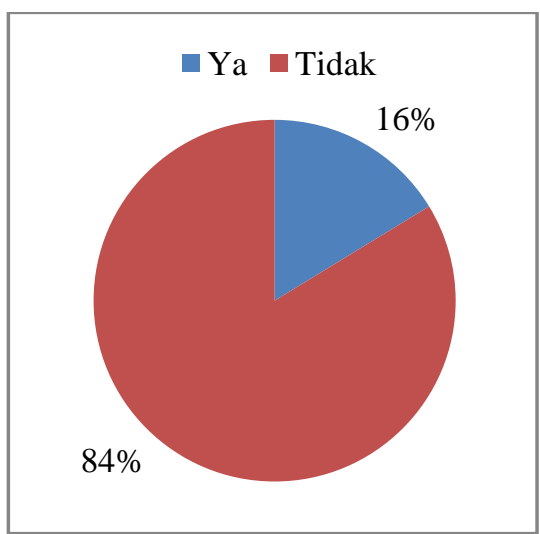

Gambar 12. Pernyataan responden laki-laki tentang proses pemilahan sampah 


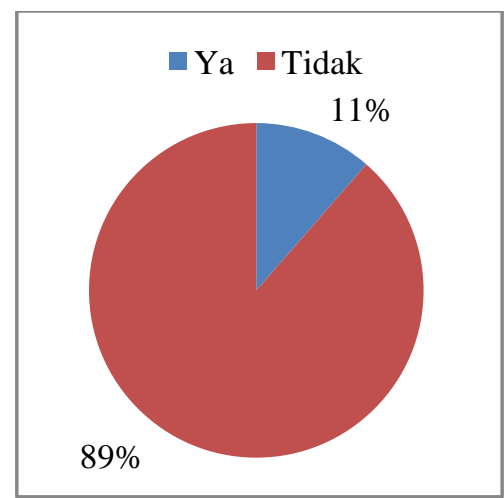

Gambar 13. Pernyataan responden perempuan tentang proses pemilahan sampah

Gambar 12 dan 13 tersebut memperlihatkan bahwa dari 43 responden siswa laki-laki, yang menjawab bahwa adanya pemilahan sampah yaitu sebanyak $16 \%$, dan yang menjawab tidak adanya pemilahan sampah yaitu sebanyak $84 \%$. Sedangkan dari 35 responden siswa perempuan, yang menjawab adanya pemilahan sampah yaitu sebanyak $11 \%$, dan yang menjawab tidak adanya pemilahan sampah yaitu sebanyak $89 \%$.

Gambar 14 menunjukkan bahwa dari 43 responden siswa laki-laki, yang menjawab bahwa tidak adanya penumpukan sampah yang terlihat setiap hari di lingkungan sekolah yaitu sebanyak 23\%, dan yang menjawab adanya penumpukan sampah yang terlihat setiap hari di lingkungan sekolah yaitu sebanyak $77 \%$.

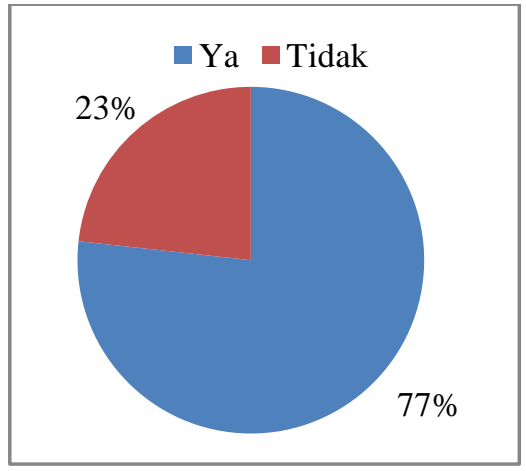

Gambar 14. Pernyataan responden laki-laki bahwa terjadi penumpukan sampah

Sedangkan Gambar 15 dari 35 responden siswa perempuan, yang menjawab tidak adanya penumpukan sampah yang terlihat setiap hari di lingkungan sekolah yaitu sebanyak $43 \%$, dan yang menjawab adanya penumpukan sampah yang terlihat setiap hari di lingkungan sekolah yaitu sebanyak 57\%.

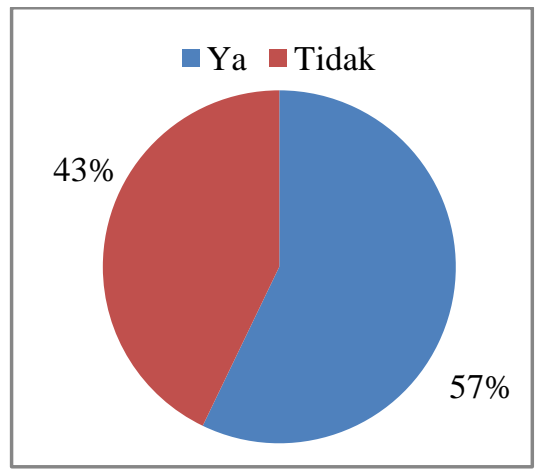

Gambar 15. Pernyataan responden perempuan bahwa terjadi penumpukan sampah

\section{Hasil Pengamatan Timbulan Sampah}

Pengamatan timbulan sampah dilakukan selama 5 hari yaitu dari hari senin sampai jumat, pengamatan selama 5 hari sudah cukup mewakili timbulan sampah selama satu minggu, karena pada hari sabtu dan minggu sekolah libur sehingga tidak ada kegiatan. Timbulan sampah yang terjadi selama 5 hari diasumsikan sebagai rata-rata timbulan sampah yang terjadi setiap hari.

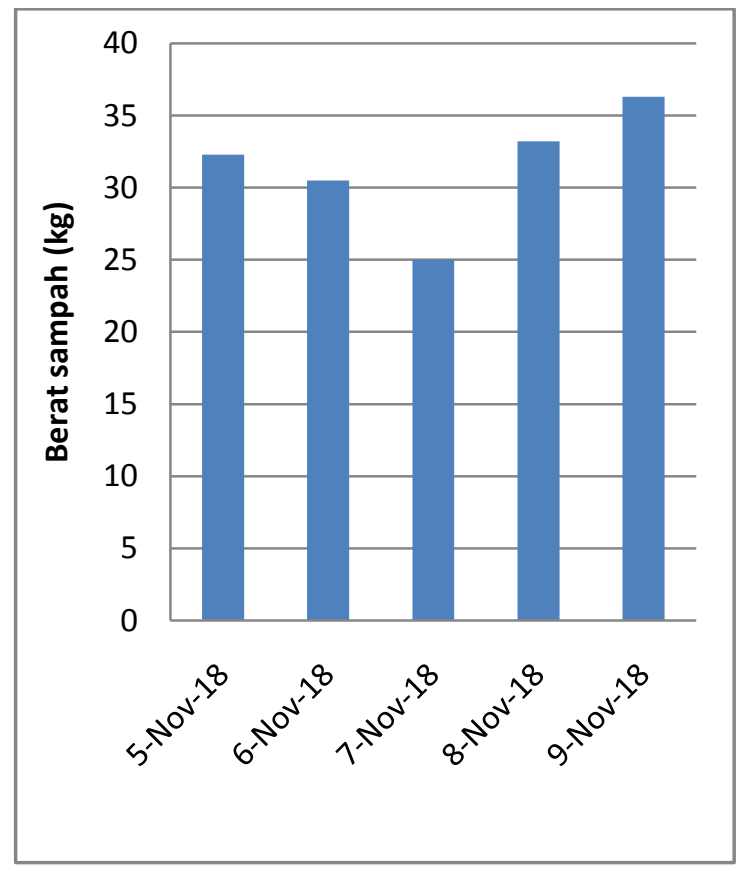

Gambar 16. Berat sampah hasil pengamatan 
Berdasarkan data hasil pemilahan sampah, diperoleh bahwa SMK Negeri Compreng sebagian besar termasuk sampah organik (sisa makanan, daun, dll) dan sampah kertas, dengan berat sampah organic (sisa makanan, daun, dll) paling tinggi sebesar $12,7 \mathrm{~kg}$ di hari ke 5 pemilahan dan untuk sampah kertas sebesar 20,2 $\mathrm{kg}$ di hari ke 4 pemilahan.

\section{Fasilias Sanitasi secara Umum}

Dari hasil persentase kuisoner keseluruhan pertanyaan yang ada di dalam kuisioner mengenai studi kelayakan sarana air bersih, responden yang menjawab layak sebesar $79,4 \%$ dan responden yang menjawab tidak layak sebesar 20,6\%. Tanggapan responden terkait studi kelayakan fasilitas sarana air limbah memperlihatkan bahwa responden yang menjawab tidak layak sebesar $37,1 \%$ dan responden yang menjawab layak sebesar $62,9 \%$. Mengenai kelayakan fasilitas sarana drainase, responden yang menjawab bahwa fasilitas drainase masih layak sebesar $32,4 \%$ dan responden yang menjawab tidak layak/rusak sebesar 67,6\%. Mengenai kondisi fasilitas sarana persampahan, responden yang menjawab tidak layak sebesar $59,2 \%$ dan responden yang menjawab bahwa sarana persampahan masih layak digunakan sebesar 40,8\%.

Berdasarkan data tersebut, maka dapat dihitung secara umum kelayakan fasilitas sanitasi.

- Responden menjawab layak : $=\frac{79,4 \%+62,9 \%+32,4 \%+40,8 \%}{400 \%}$ $=54 \%$

- Responden menjawab tidak layak :

$$
\begin{aligned}
& =\frac{20,6 \%+37,1 \%+67,6 \%+59,2 \%}{400 \%} \\
& =46 \%
\end{aligned}
$$

\section{Kesimpulan}

Berdasarkan hasil analisis umum maka didapat untuk keseluruhan jawaban positif (sarana fasilitas sanitasi layak digunakan/memadai) sebesar 54\% dan untuk jawaban negatif (tidak layak digunakan) sebesar $46 \%$. Dapat disimpulkan bahwa hampir setengah dari responden siswa dan siswi SMK Negeri Compreng merasakan fasilitas sanitasi di sekolah belum memadai dan butuh perbaikan atau penambahan fasilitas, terutama untuk sarana saluran drainase untuk mengalirkan air hujan guna mencegah genangan atau banjir dan fasilitas untuk mengelola timbulan sampah yang terjadi di SMK Negeri Compreng ini.

\section{Daftar Pustaka}

Atmoko, T. P. (2017). Peningkatan Higiene Sanitasi Sebagai Upaya Menjaga Kualitas Makanan Dan Peningkatan Higiene Sanitasi Sebagai Upaya Menjaga Kualitas Makanan Dan. Jurnal Khasanah Ilmu, Vol. 8, No. 1: 1-9.

Santi, A. U., \& Bahiij, A. a. (2018). Kondisi Sanitasi di Tiga Sekolah Dasar Negeri di Daerah Tangerang Selatan. Holistika Jurnal Ilmiah PGSD, Vol. 2, No 1: 30-36.

Sevilla, \& al, e. (2007). Research Methods. Quezon City: Rex Printing Company. 